\title{
Soil water crop modeling for decision support in millet- based systems in the Sahel: a challenge
}

\author{
Akponikpè P. B. I. ${ }^{1 *}$, Gérard B. ${ }^{2}$ and Bielders C. L. ${ }^{3}$ \\ ${ }^{1}$ Université de Parakou (UP), Faculté d'Agronomie (FA), Unit of Environmental Soil Physics and Hydraulics (PSHE / \\ ESPH), 03 BP 351 Université, Parakou, Benin. \\ ${ }^{2}$ Global Conservation Agriculture Program at CIMMYT (International Maize and Wheat Improvement Center), Apdo. \\ Postal 6-641, 06600 Mexico City, D.F., Mexico. \\ ${ }^{3}$ Université catholique de Louvain (UCL), Earth and Life Institute. Croix du Sud 2, Box 2, B-1348 \\ Louvain-la-Neuve, Belgium.
}

Received 12 April, 2010; Accepted 12 August, 2010

\begin{abstract}
Food insecurity in the Sahelian environment was extensively shown to be a result of low soil fertility and high climate risks. But decisions and recommendations made from the great wealth of research have little been adopted by farmers. Soil water crop models (SWCM) can assist researchers and development actors in this environment if they can appropriately deal with the constraints and mainly farmers' agricultural development goals. We reviewed the Sahelian agricultural constraints and farmer management practices with an emphasis on Niger and pearl millet. Significant results derived from research works to improve crop productivity are presented and analyzed with regard to the main agricultural constraints. Potential and currently used SWCMs are presented and compared for relevance for use in such a particular environment for decision support (DS). This shows that crop modeling in millet-based agricultural system of the Sahel should be addressed with an integrated approach that can handle the multiple and usually connected agricultural constraints of the region: low soil fertility and spatial variability, time and space rainfall variability. Recommendations were made regarding the relevant and minimum aspects that SWCM should take into account for a successful and reliable use for DS in the complex Sahelian environment.
\end{abstract}

Key words: Rainfall variability, simulation, nutrients, climate change, climatic risks, soil fertility.

\section{INTRODUCTION}

Smallholder farmers in the Sahelian zone of sub-Saharan Africa are facing difficult times as a result of productivity levels that are often low. Millet grain yields are often below $500 \mathrm{~kg}$ ha-1 (De Rouw, 2004). Crop yields are strongly dependent on, and constrained by what has been recently recognized (after many decades of blaming only water stress) as the most important asset-soil fertility (Struif Bontkes and Wopereis, 2003). The unfavorable climate and low fertility create intense pressure on land even at relatively low population densities (Reardon et al., 1997). Decision making have long been derived from the great wealth of research undertaken in the area but these constraints are still impeding the development of sahelian farmers' 
agricultural systems. There is a need for tools that can support decision making. Agricultural decision support tools (DSTs) integrate information or knowledge about soil, climate, crops, and management for making better decisions about crop production and food security. In the Sahel such DSTs can assist with the diagnosis and analysis of problems and opportunities related to water, soil fertility, and farmers endogenous practices. Several DSTs have been developed over the past decades; they range from simple best-bet options tables to sophisticated computer models (Struif Bontkes and Wopereis, 2003).

A computer model is a simplified representation of reality with which we can compute outcomes without having to perform actual experiments. The soil-watercrop models (SWCM) are computer models that can be used to predict crop yield under different management strategies, as well as individual land properties or characteristics that are important components of yield, such as moisture supply, nutrient supply, and radiation balance etc. Giving a comprehensive list of possible applications of SWCMs as DS is impossible because DS is an art of the user and mostly depends on the specific problem under study. Known applications are diverse and include crop managements (rotation, fallow), soil fertility management, water management, climate variability and risk analysis, climate adaptation, weed, pest, disease management etc. But an interesting SWCM to be used for DS should at least comply with two main criteria: 1) suitability for the target environment and 2) appropriateness for the intended purpose (CLIMAG-WA, 2002). The use of SWCM for DS is widely practiced for many regions and crops in the world but in the sahelian millet-based systems it is still far from common. To improve this situation, this review paper first analyzes the agricultural constraints for millet-based systems in the Sahelian region with respect to local farmers' practices and research outcomes. Then an overview of potential or currently used SWCMs in semi-arid Africa is given. And finally the role that these models may play in such an environment is discussed.

\section{Main agricultural constraints in millet-based cropping systems in the Sahel}

\section{Rainfall uncertainty and variability in time and space}

The general atmospheric circulation is a major factor influencing climate variation in west Africa. In Niger, the single-peak rainy season occurs in the period from May to September, with the remainder of the year dry. The length of the rainy season ranges from 60 days $(250 \mathrm{~mm}$ year ${ }^{-1}$ isohyet) to 120 days ( $750 \mathrm{~mm}_{\text {year }}{ }^{-1}$ isohyet). Millet is grown throughout the semi-arid zone, but is dominant within the 250-750 mm year ${ }^{-1}$ zone (Hoogmoed and Klaij, 1990). The annual potential evapotranspiration is high $\left(2000-2300 \mathrm{~mm}\right.$ year $\left.^{-1}\right)$ (Sivakumar et al., 1993).
Moreover, a long term rainfall trend towards aridification was reported especially for northern rainfall stations and a comparison of different annual rainfall datasets shows that the isohyets have shifted $100-150 \mathrm{~km}$ southward since the 1960s (Sivakumar et al., 1993). A close relationship between the Sahelian rainfall decrease and the reduction in the number of rainy days has been confirmed by Le Barbé and Lebel (1997). They observed a decrease in both the seasonal amount and number of rainfall events of about $25 \%$. But recently, this trend towards aridification became a very controversial issue. While some authors reported the drought to be ending since the 1990 (e.g., Ozer et al., 2003), or being simply an artifact of changing station networks (Chappell and Agnew, 2004) others as L'hote et al. (2002, 2003), Dai et al. (2004) and Hulme (2001) argued it to be real and continuing.

Beside the long term trend, the temporal variability of rainfall is very high on the annual, monthly and daily time scales. The monthly rainfall variability is more distinct since rainfall occurs only during the 3 to 5 summer months. More crucial to agriculture is the daily variability. The average amount of rain per rainy day increases from 9.7 to $14.4 \mathrm{~mm}$ during the course of the rainy season, while the standard deviation increased at the same time from 7.6 to $11.1 \mathrm{~mm}$. The mean duration between successive rain events progressively decreases during the wet season from 6 to 2 days. Mean maxima per rainy day in July and August are 45 and $48 \mathrm{~mm}$ day $^{-1}$, respectively (Sivakumar et al., 1993).

The Sahelian zone is characterized by a strong NorthSouth annual rainfall gradient, with $1 \mathrm{~mm}$ decrease on average for every $\mathrm{km}$. Beside this general latidunal trend, annual differences of 200 to $300 \mathrm{~mm}$ may occur in any directions within a radius of only $100 \mathrm{~km}$. At ICRISAT Sahelian center, total annual rainfall in 1995 ranged from 440 to $553 \mathrm{~mm}$ over only $2.5 \mathrm{~km}$ distance, while in 1996 it ranges from 503 to $554 \mathrm{~mm}$ over $0.8 \mathrm{~km}$ distance which correspond to maximum gradients of 42 and $64 \mathrm{~mm} \mathrm{~km}^{-1}$, respectively (Graef, 2000). The same author mentioned that single rainfall gradients may exceed $20 \mathrm{~mm}$ over 3.2 $\mathrm{km}$ distance during a single event. So spatial rainfall variability is higher at a local scale than at regional scale. The strong local scale rainfall variability is an agroclimatic risk factor that farmers have to deal with in the Sahel and farmer's fields are found to be dispersed within 1 to $5 \mathrm{~km}$ distance (Graef and Haigis, 2001). Akponikpè et al., (2011) using a modeling approach, confirmed the effectiveness of this farmer fields' dispersion strategy to reduce the disparity of millet yield between households each year and to increase the inter-annual yield stability at household level.

\section{Poor and highly variable soil physical and chemical characteristics}

Based on data from the Fakara region (Hiernaux and 
Ayantunde, 2004) and ICRISAT Sahelian center, Sadoré, the soils were classified as sandy, with more than $90 \%$ sand in the A horizon (West et al., 1984). Soils have a $\mathrm{pH}$-water of 4.5 to 6.3 , CEC of 0.8 to $7.0 \mathrm{meq} / 100 \mathrm{~g}$, organic matter content of 0.1 to $0.80 \%$, total $\mathrm{N}$ of 100 to $300 \mathrm{mg} \mathrm{kg}^{-1}$ and total $\mathrm{P}$ of 0.7 to $5.5 \mathrm{mg} \mathrm{kg}^{-1}$. Soil water at field capacity is of the order of $0.10 \mathrm{~cm}^{3} \mathrm{~cm}^{-3}$ (Klaij and Vachaud, 1992). High variability were reported over short distances (2m) (e.g., Geiger and Manu, 1993; Manu et al., 1996; Rockstrom, 1999; Voortman et al., 2004).

The soils are of structureless class with high percentage of coarse sand particle (Hoogmoed and Klaij, 1990). Differences in soil properties are thought to be caused by differential wind and water erosion and deposition, growth of trees and shrubs before clearing for cultivation, trees left standing such as Faidherbia albida, termite activity, differential leaching, and/or human activity (including uneven application of manure, location of village sites and refuse heaps, and burning of cleared vegetation)(Miedema et al., 1994; Geiger et al., 1994; Gérard and Buerkert, 1999; De Rouw and Rajot, 2004).

\section{Millet growth and yield variability in space and time}

Millet germinates uniformly across fields, but 1 to 2 weeks after emergence, differences in growth occur (Scott-Wendt et al., 1988a). This short-range variability results in low yields in farmers' field and experiments. Using a scoring harvest technique in 1993 , on a $40 \times 60$ $\mathrm{m}$ plot, grain yield in the sub-plots $(4 \times 5 \mathrm{~m})$ at the end of the growing season ranged from 1.6 to $137.9 \mathrm{~g} \mathrm{~m}^{-2}$, with an average of $63.9 \mathrm{~g} \mathrm{~m}^{-2}$. The total biomass measured in the sub-plots ranged from 16.0 to $450.0 \mathrm{~g} \mathrm{~m}^{-2}$, with an average value of $234.7 \mathrm{~g} \mathrm{~m}^{-2}$ (Scott-Wendt et al., 1988a). Many attempts were made to explain the cause of this large millet yield variability. Some authors have observed that often, although not consistently, millet growth is better on micro-high conditions and poorer in micro-low situations (Scott-Wendt et al., 1988b; Geiger and Manu, 1993; Manu et al., 1996). Scott-Wendt et al. (1988b) investigated a transect from very poorly growing to wellgrowing millet and observed that low yields were correlated with high Aluminium saturation levels and lower cation levels $(\mathrm{Ca}, \mathrm{Mg}$, and $\mathrm{K})$. Voortman et al. (Voortman et al., 2004) showed that the proportion of the cations ( $\mathrm{Ca}, \mathrm{Mg}, \mathrm{K}$ and $\mathrm{Na}$ ) on the exchange complex, in combination with the Al saturation profile were the main source of spatial variability at this scale where these soil properties explained $82 \%$ of the millet yield variation. They pointed out that macronutrients $\mathrm{N}, \mathrm{P}, \mathrm{K}$ explained only a modest portion of millet yield spatial variability.

Termite activity was also mentioned as another factor inducing spatial yield variability. According to Miedeman et al. (1994), good growth sites were associated with a higher level of termite-derived pedofeatures (termite infillings) and termite amended groundmass features (bridged grain microstructures). They explained this by an enrichment of soil-surface with organic matter and fine clayey material as a result of termite activity which cause a better chemical fertility status and a better water holding capacity.

In time (between seasons), yield variation were explained by rainfall pattern with the main determinants being the date of rain onset, number and length of dry spells, and water by nutrient interaction (Akponikpè et al., 2010). In fact rain onset is very wide (April to July), the average date (and standard deviation) of onset of the rainy season is 12 June (18 days) while rain stops approximately at the same time every year at 27 September (12 days), causing late sowings to suffer from end season water stress (Sivakumar, 1988, 1990). Frequent occurrence of dry spells were reported to impede on millet development and yield establishment mainly during sensitive phenology stages such as flowering and grain filling (Sivakumar, 1992; Winkel et al., 1997). Interaction between water and nutrient availability was frequently reported to explain millet yield variability between years. For instance, Gandah et al. (2000) observed that maximum yield was not observed at the same place in farmer field every year (under the same fertility practice). Christianson et al. (1990) tried to explain the millet grain yield as a function of $\mathrm{N}$ rate and annual or mid-season rainfall amount.

\section{Farmer soil fertility management practices and research findings}

\section{Manure and corralling of livestock (on fields)}

Smallholder farmers employ a range of technologies to enhance soil fertility, and manure is a cornerstone of many of the soil fertility management strategies they use. Manure is composed of all sort of feaces, urine, refuse fodder, vegetation added to the compost to trap urine, cooking waste and ash from cooking fire (Harris, 2002). Large cattle or small ruminant manure application is devoted to limited spots within farmers' fields and often applied (corralling livestock on field or transported farm yard manure) at very high application rates. Manure application was targeted to spots in only $30 \%$ of 307 fields surveyed by Schlecht et al. (2004) in a recent survey around Chikal, southwestern Niger.

Schlecht et al. (2004) collected data from southwestern Fulani (herders) and Zarma villages in southwestern Niger (Ticko, Kodey, Tigo-tegui, Banizoumbou) and found on corralling and manuring practices, average application rates of 12.7 to $15.5 \mathrm{t} \mathrm{ha}^{-1}$ feacal dry matter (FDM) for cattle and 6.8 to $7.2 \mathrm{t} \mathrm{ha}^{-1}$ (FDM) for sheep and goats. Average manure application rates in Chikal were much lower, varying around $3.4 \mathrm{t} \mathrm{ha}^{-1}$ and $1.3 \mathrm{t} \mathrm{ha}^{-1}$ FDM for cattle and for small ruminants. Akponikpè (2008) found 0.05 to $4.9 \mathrm{t} \mathrm{ha}^{-1}$ in corralled spots and 0.0 to $1.0 \mathrm{t} \mathrm{ha}^{-1}$ in 
farmyard manure spots within farmers field in the same area (Kodey, Tigo-tegui, Bagoua and Banizoumbou) in 2004. The amount application varies according to the farmer cattle herd size and the extent and spatial homogeneity of application depends on his capacity to assure a good distribution of the manure in the spots during corralling or farmyard manure transportation. Manuring of the same field or spot is normally repeated only every 3rd-5th year. In general, more farmers opt for the longer interval between applications than the shorter one (Schlecht et al., 2004).

Manure received much scientific attention (Williams, 1999; Harris, 2002; Schlecht et al., 2004). The effect of different manuring and corralling treatments on millet yield in the Sahel vary widely. Having tested from 1997 to 2001 five rates of application of cattle manure, that is, 2 , $4,6,10$, and $14 \mathrm{t} \mathrm{ha}^{-1}$ of fecal dry matter on a millet landrace, Schlecht et al. (2004) found that millet dry matter yields exceeded (on average over 4 consecutive years) the yield of the control by $779 \pm 84 \mathrm{~kg} \mathrm{ha}^{-1}$ of grain and $1822 \pm 233 \mathrm{~kg} \mathrm{ha}^{-1}$ of stover when $2 \mathrm{t} \mathrm{ha}^{-1}$ of manure were applied in the first year. The yield response of millet increased linearly with the rate of manure application in the first year, at least up to $14 \mathrm{tha}^{-1}$ of FDM. Some onfarm experiments (Tigo, southwestern Niger) showed that the residual effect of manuring was still significant 3 years after application ( $6 \mathrm{t} \mathrm{ha}^{-1}$ manure $+2 \mathrm{t} \mathrm{ha}^{-1}$ crop residue), with grain yields of $527 \pm 56 \mathrm{~kg} \mathrm{DM} \mathrm{ha}^{-1}$ versus $298 \pm 54$ $\mathrm{kg} \mathrm{DM} \mathrm{ha-1}$ in the control (Schlecht et al., 2004). Underlying beneficial effects of manure are increased soil porosity and aggregate stability, increased water infiltration and water holding capacity, decreased eolian soil losses, increased SOM, pH, CEC and nutrient availability (e.g., Bationo and Mokwunye, 1991a; Buerkert and Hiernaux, 1998; Schlecht et al., 2004). But the quality of manure produced by livestock and their effect on crop vary according to their diet (Powell et al., 1994; Tittonell et al., 2007). Other works have pointed out the beneficial effect associated with the application of urine during corralling (Powell et al., 1998; Sangaré et al., 2002).

Large manure application rates usually results in high nutrient loss on the acidic and sandy soil of Niger. On average, $1070 \mathrm{~kg} \mathrm{ha}^{-1}$ of $\mathrm{C}, 91 \mathrm{~kg} \mathrm{ha}^{-1}$ of $\mathrm{N}, 19 \mathrm{~kg} \mathrm{ha}^{-1}$ of $\mathrm{P}$ were leached to depth between 1.5 and $2 \mathrm{~m}$ at high rates (9 to $10 \mathrm{t} \mathrm{ha}^{-1}$ ) of manure application (Brouwer and Powell, 1998).

They suggested application to be less than $2.8 \mathrm{t} \mathrm{ha}^{-1}$ on topographical lows (prone to high run-on and rainfall infiltration) and $2.5 \mathrm{t} \mathrm{ha}^{-1}$ on higher parts (prone to runoff and low rainfall infiltration) of farmer's field. But these recommendations do not take into account the highly variable quality of the manure (Harris, 2002) and its low availability in the area. One strategy to increase the nutrient efficiency, well known to farmers but labour demanding, is the placement of the manure in planting pits (zaï) (Fatondji, 2002; Fatondji et al., 2006).

\section{Crop residues}

Traditionally farmer remove millet residues from farms, after grain harvest, for household uses (fencing, fuel, animal feeding, bed or granary making) or sell them to herders (Baidu-Forson, 1995; Bationo et al., 1995). So little crop residues are left on farms. Schlecht and Buerkert (2004) found in a recent survey in Chikal territory, southwestern Niger that mulching of crop residues was mainly practiced to fight wind erosion but was restricted to $36 \%$ of 307 individual farmers' fields given the alternative uses of straw. Quantities of stover found on farms in the Sahel before millet sowing are less than $800 \mathrm{~kg} \mathrm{ha}^{-1}$ and mostly inadequate for effective mulching (Baidu-Forson, 1995).

As it is encountered within farmer field prior to sowing, crop residue has benefited from extended research attention. Especially long-term but also short-term application of crop residue (mulching) increases pearl millet yield, whereas their omission decreases yield immediately. For Sahelian climatic conditions, the sandy soils of western Niger and application rates up to $4 \mathrm{t} \mathrm{ha}^{-1}$, no depressive effect of crop residue on millet yield has ever been reported.

Incorporation of crop residues gave higher yield compared to mulching or burning (Rebafka et al., 1994). The mechanisms responsible for the positive effect of crop residue on crop are physical and chemical. Physical effects comprise: reduced wind and erosion effect on nutrient that enhance seedling emergence and early growth (Michels et al., 1995; Bielders et al., 2000, 2001, 2002; Buerkert et al., 2000), reduction in surface crusting, increase formation of stable aggregates improving soil porosity and water infiltration (Hoogmoed and Stroosnijder, 1984; Buerkert and Stern, 1995) and a decrease in soil surface temperature (Buerkert and Lamers, 1999; Buerkert et al., 2000). Chemical mulching effects are related to: (1) increase exchangeable base content and cation exchange capacity (CEC), lower Al saturation, increase in plant available phosphorus and potassium, and $\mathrm{P}$ mobility (Kretzschmar et al., 1991; Geiger et al., 1992; Bationo et al., 1993; Hafner et al., 1993; Rebafka et al., 1994). The rate of crop residue generally tested in research or recommended are far higher than what are encountered in farmer fields before sowing and even exceed annual stover yield, which raises questions about their relevance.

\section{Mineral fertilizer}

Millet-based farming system in the Sahel is characterized by no or low inputs of fertilizer. Farmers usually mix small quantities of fertilizer with seed at sowing. Because of the low availability of crop residue and manure in the Sahel, more attention was given by research to mineral fertilizer use in order to alleviate soil fertility constraints. Although 
some authors have reported large responses to $\mathrm{K}$ fertilizer (Rebafka et al., 1994), mineral fertilizer strategies have generally focused on satisfying plant $\mathrm{N}$ and $\mathrm{P}$ requirements, the two most limiting nutrients (Bationo et al., 2003). There is no positive response to $\mathrm{N}$ unless adequate $\mathrm{P}$ is supplied (Buerkert and Stern, 1995; Buerkert et al., 2001). There were many research works done to prove the beneficial effect of $\mathrm{N}$ and manly $\mathrm{P}$ fertilizer in the area (e.g., Christianson et al., 1990; Bationo et al., 1992; Subbarao et al., 2000; Bationo and Ntare, 2000; Buerkert et al., 2001; Yamoah et al., 2002). Single superphosphate (SSP) applied annually at $13 \mathrm{~kg} \mathrm{P}$ $\mathrm{ha}^{-1}$ effectively removed $\mathrm{P}$ deficiency on most cases. Rockphosphate (RP) from various regional sources (RP compacted with soluble fertilizer and partially acidulated phosphate rock (PAPR)) have also been tested and shown to vary widely in their efficiency (Bationo et al., 1990a; Bationo and Mokwunye, 1991b). Phosphorusinduced yield increases in millet have been shown to substantially increase with $\mathrm{N}$ application. Most research examined the immediate millet response of single or repeated application of soluble $\mathrm{N}$ and $\mathrm{P}$ and little is known about residual effects on plant growth over time, although this is crucial to predict adoption by smallholder farmers (Schlecht et al., 2006). Moreover there is evidence that on weakly buffered Sahelian soils the use of mineral fertilizers may lead to rapid decrease in soil organic matter (SOM) and $\mathrm{pH}$, thereby detrimentally affecting millet production. To be sustainable, any longterm application of mineral fertilizers to Sahelian soils will need to be combined with the application of organic matter.

\section{Combined organic amendment and mineral fertilizer}

Although the effectiveness of manure, crop residue or fertilizers for improving soil fertility and crop yields has been demonstrated repeatedly through on-station and on-farm trials (e.g., Bationo and Mokwunye, 1991b; Brouwer and Powell, 1998), all these sources are limited for farmers' use by either availability (Palm et al., 1997), competing uses (Bationo et al., 1995; Lamers et al., 1998) and price or financial risk (Shapiro and Sanders, 1998). Hence, an integrated nutrient management (INM) which relies on the use of multiple sources of nutrients sources (various organic and mineral fertilizer) is a necessity in order to achieve productive and sustainable agricultural systems (Palm et al., 1997; Kimani et al., 2003).

Additive, but also synergetic (more than proportional) effects have been reported in the literature as a result of the combined use of organic and inorganic amendments (e.g., Bationo et al., 1993; Hafner et al., 1993; Kimetu et al., 2004; Akponikpè et al., 2008). In Niger, phosphorus use efficiency for millet ( $\mathrm{kg}$ grain $/ \mathrm{kg}$ applied $\mathrm{P}$ ) was increased from 46 on plots fertilized with inorganic $P$ to
86 on plots amended with inorganic $\mathrm{N}$ and $\mathrm{P}$ and millet crop residue (Bationo et al., 2003). On average over a 9year experiment, Yamoah et al. (2002) reported that millet grain yield increased from $320 \mathrm{~kg} \mathrm{ha}^{-1}$ on control plots to 700,900 and $1510 \mathrm{~kg} \mathrm{ha}^{-1}$ on plots amended with residue, $N$ \& $P$ fertilizer and residue $+N$ \& $P$ fertilizer, respectively. Similar trends were reported for millet stover yield. Water use efficiency was raised from 0.78 $\mathrm{kg}$ grain ha $\mathrm{mm}^{-1}$ for the control to $3.61 \mathrm{~kg} \mathrm{ha}^{-1} \mathrm{~mm}^{-1}$ for the residue+fertilizer plots. Fertilizer use efficiency $(\mathrm{kg}$ grain $\mathrm{kg}^{-1}$ fertilizer) was 13.5 for the fertilized plots and increased to 27.6 upon the addition of residue. Yamoah et al. (2002) concluded that the residue+fertilizer treatment had the highest sustainability yield index.

These synergetic effects may result from the side effects of using organic fertilizers, besides their role as nutrient providers: $P$ mobility enhancement, decrease in exchangeable Al, enhancement of root growth, decreased surface temperature and soil penetration resistance, and soil protection against wind erosion (Bielders et al., 2000; Buerkert et al., 2000). A specific effect of INM is to also to maximize nutrient use efficiency (Kimani et al., 2003). In millet-based rainfed systems, this goes along with a strong increase in water use efficiency, as seasonal cumulative evapotranspiration is little affected by fertility management practices (Payne, 2000). Whereas fertilizers release their nutrients rather rapidly, manure or residue act as slow release fertilizers. In addition, they are a source of multiple nutrients, including micronutrients, supply carbon for soil micro-organisms involved in nutrient cycling, and may improve soil physical and chemical quality (Buerkert et al., 2000; Esse et al., 2001; Harris, 2002). The use of either crop residue or manure can buffer soil acidification resulting from fertilizer use, thereby enhancing fertilizer use efficiency by preventing P immobilization (e.g., Hafner et al., 1993).

\section{Analysis of traditional and proposed technologies and need of decision support tools}

\section{Sustainability of research proposed versus traditional technologies}

Subbarao et al. (2000) studied the long-term effects of tillage, phosphorus fertilization and crop rotation on pearl millet productivity at Sadoré and found that the traditional system was more stable although it had the lowest yield. In another case study combining 13 alternative technologies ranging from sole millet or intercropping, improved cultivars, $\mathrm{P}$ fertilizer application, tillage and rotation Subbarao et al. (2000) found again the traditional production system to be more stable. As the degree of intensification increased in the Sahel, the stability of the production system declines (Subbarao et al., 1999). De Rouw (2004) found similar results regarding plant densities as conventional low density 
planting did not produce high yields as frequently as higher densities under favorable conditions. However, there was less crop failure under harsh conditions with low density sowing, although lower average grain yields were realized.

\section{The Sahel: A complex agricultural research environment}

Many authors have emphasized that the interpretation of experimental research is often difficult because the soils which have developed in coversand materials, although uniformly very sandy, exhibit a great spatial variability within distances as short as few meters (Voortman et al., 2004). The local soil variability leads to large variations among replications of experimental treatments. Moreover annual rainfall variability causes research results not to be consistent from year to year and there is a poor comparability of results across locations and climatic conditions (Schlecht et al., 2006).

\section{Level of adoption of proposed technologies and need for decision support tools}

Research efforts have provided the foundation for extension in Sahelian countries. In Niger, for example, extension has formulated a set of proposals (Reddy, 1988; Klaij et al., 1994): (i) Higher plant densities were recommended as a means to achieve higher yields at low cost. However, significant increases in density should only be made in conjunction with mineral fertilizer use; (ii) modest quantities of $\mathrm{N}$ and $\mathrm{P}$ should be applied next to individual hills for their most effective use and this increases the risk of crop failure in poor rainfall years (De Rouw, 2004); (iii) selected short cycle cultivars should replace the local landraces, especially if the rains are late. As a consequence, these proposals were tested further in suitable rainfall zones throughout Niger (INRAN, 1990) and were applied in many development projects (Ukkerman and Hama, 1995).

However, these recommendations have not been widely adopted. Selected cultivars, mineral fertilizers, and cropping practices such as higher stand density have been used by only a few farmers within the development projects and none else (Abdoulaye and LowenbergDeboer, 2000). Fertilizer recommendations are often based on nutrient response trials limited to a few years and locations. Sometimes standard or "blanket" recommendations are applied for whole agro-ecological regions or even the whole country (Vanlauwe and Giller, 2006). It is hard, in this sense, for extension services to match research findings to farmers local site conditions which may not be comparable to on-station or on-farm conditions found elsewhere. Recommendations need to be more flexible. In addition, the difference in priorities between researchers, who aim to improve yields in average years, and Sahelian farmers, who seek to reduce the frequency of crop failure, could explain the non-adoption of most innovations because the risks of yield losses were not reduced (De Rouw, 2004). Farmers are familiar with, and apply soil fertility improvement techniques of mineral fertilizer (including rock phosphate), crop residue, cattle and farmyard manure and crop rotation. According to Enyong et al. (1999) farmers attitudes to and rationales behind adoption are influenced by the availability and land use policies and available labor resources, food security concerns, perceived profitability, contribution to sustainability and access to information. But some of the factors are beyond farmers' control and require a broad and integrated effort from research, extension and government to promote the use of the fertility improvement technologies in the region.

Given the complexity and heterogeneity of the milletbased cropping systems in the Sahel, the situation undoubtedly calls for comprehensive, easy and low cost tools. DSTs such as numerical soil-water-crop simulation models could play a key role, helping in saving time and money from long years of field/station experiments and capitalizing on farmers' local knowledge and existing research findings.

\section{State of the art of soil-water-crop modeling in the semi-arid Africa}

SWCMs will be shortly described and experience of their use in the Sahelian context will be presented highlighting successes and shortcomings. SWCMs are presented following chronological order of use in the crop yield modeling science. Statistical models have been used for yield prediction for several decades, water-balance models took up the challenge by tackling water requirement satisfaction in relation to crop production. More recently efforts were made to take into account processes related to plant nutrient interactions. Although potentially important, modeling of biotic stresses (weed, pests, diseases, etc) will not be discussed here.

\section{Empirical-statistical models}

This approach goes back to the 1930's and is the oldest form of crop modeling. Yield is predicted as a statistical function of observed key environmental characteristic averaged over part or all of the growing season (e.g., Thompson, 1986; Dourado-Neto et al., 1998a, b). The statistical functions are usually developed by simple/multiple regression techniques (stepwise linear, ordinary least squares (OLS) and maximum likelihood estimation (ML). These environmental characteristics are typically climate (precipitation, solar radiation and 
temperature, evapotranspiration averaged over the growing season or over specific periods) and soil (nutrient status, organic matter content, particle -size distribution). Although these models may have a role under particular circumstances, they have been largely replaced by models that are more or less dynamic, at least with respect to the soil water balance. Examples in the millet-based Sahelian system explained millet grain yield as a function of $\mathrm{N}$ rate and annual or mid-season rainfall (Christianson et al., 1990); N rate, plant density and rainfall during particular crop phase (Bationo et al., 1990b), N, P and /or K rates (Fussell et al., 1987); N, P and $K$ rates with other soil, terrain and management variables (Voortman and Brouwer, 2003). As with any empirical model, these models can only be applied in their original zone of calibration. Extrapolation to new conditions is not warranted. Although these models may have a role under particular circumstances, they have been largely replaced by models that are more or less dynamic, at least with respect to the soil water balance.

\section{Water-balance (stress index models)}

Due to soil constraints for efficient water use, and the critical importance of available water to food security in semi-arid West Africa, considerable regional effort has been devoted to water balance studies and models. Dynamic water balance models simulate infiltration, runoff, drainage and evaporation from soil. Simple descriptions of crop canopy development permit calculation of transpiration (CLIMAG-WA, 2002). A stress index such as the time integral of the ratio of actual to potential transpiration can be related empirically to reduction of growth and yield. The stress index approach (Doorenbos and Pruitt, 1977) is not fundamentally different from that used in dynamic process crop models. Canopy characteristics are taken as an input rather than a dynamic state variable greatly simplifies the model but also does not permit to take into account feedback mechanisms, such as early-season water stress and later-season demand. Water balance - stress index models have been applied to a broader range of scales than process models. They are applied in West African countries for agrometeorological and food security assessments. SARRAH-based models (Système d'Analyse Régional des Risques Agroclimatiques-Habillé) typically and deterministically simulate attainable yields (water-limited under optimal soil fertility condition) at the field scale, but may also be stochastic and operate at variable temporal and spatial scales (Samba, 1998; Baron et al., 1999). Extrapolation from plot to region is done by AGRHYMET (Niamey) for agro-meteorological forecasting using the DHC system ("Diagnostic Hydrique des Cultures"), which includes SARRA as a component (Samba, 1998). A specific sub-model was developed for millet (SARRA-millet or SARRAH-mil) and was structured to enable such applications as well, but with greater physiological detail. It is frequently used by agronomists and agro-meteorologists working in the Sahel. It has been used for zoning and risk analyses (Affholder, 1997; Baron et al., 1999; Sultan et al., 2005a), to analyze the impact of regional climatic variability on millet yield (Sultan et al., 2005b) and to predict agricultural plot yield based on Global Circulation Model output (Baron et al., 2005).

\section{Dynamic process models}

Over the past 25 years, many individual modelers and collaborative groups have attempted to develop models that simulate the growth of crops, along with associated phenomena that influence crop growth such as water and solute movement in soils. Dynamic process models are then those which simulate through time (usually on a daily or sub-daily time step) the ecological and physiological processes of crop growth, development and interaction with the environment. Experience has led to a distinction between mechanistic models that try to capture our understanding of the mechanisms behind subsets of those processes with the primary objective to advance our understanding, and functional models that make useful simplifications so that data requirements and the robustness of predictions are appropriate for a rather broad range of practical applications (CLIMAG-WA, 2002). A short overview will be given for the five most promising and widely known ones (irrespective of age or importance): "School of de Wit", APSIM, DSSAT, STICS, Cropsyst. Examples of applications in semi-arid Africa will be given and completed with other applications in Africa in general because of the very few crop modeling works in the Sahel.

\section{"School of de Wit" models}

The modeling group from Wageningen Agricultural University, The Netherlands - nicknamed the "School of de Wit" in honor of their early crop modeling pioneer has taken a rather different approach (Bouman et al., 1996). Instead of developing comprehensive, general purpose models, they have emphasized applicationdependent models, and have developed tools to facilitate rapid development of relatively simple models(CLIMAGWA, 2002). Yet we can identify an evolving family of crop models that includes SUCROS, MACROS and WOFOST. A model for sorghum, millet and maize with a tippingbucket soil water balance model has been developed for use in the Soudano-Sahelian region (Bazi et al., 1995).

\section{APSIM}

The agricultural production systems simulator (APSIM) is 
Table 1. List of various types of applications of the APSIM crop models in Africa and example references that describe these applications in detail.

\begin{tabular}{lll}
\hline Type of application & Crop, Climatic zone and country & References \\
\hline Low input farming systems in & Maize, grain legumes (Dry and wet & $\begin{array}{l}\text { Shamudzarira et al. (2000), Shamudzarira and } \\
\text { Robertson (2002), Chivenge et al. (2004) }\end{array}$ \\
& Zimbabwe) & Kinyangi et al. (2004), Micheni et al.(2004) \\
N and P release from organic source & Maize (semi-arid and Wet Kenya) & Kpongor (2007), MacCarthy et al., (2009) \\
Water-soil fertility management & Sorghum (Semi-arid Ghana) & Akponikpè (2008), Akponikpè et al. (2010) \\
& Millet (Sahel, Niger) & Akponikpè et al. (2011), Akponikpè (2008); \\
Agro-climatic risk management & Millet (Sahel, Niger) & $\begin{array}{l}\text { Akponikpè et al. (2010), Akponikpè et al. } \\
\text { (2011), Tidjani and Akponikpe (2012), Tachie- } \\
\end{array}$ \\
& & Obeng et al. (2013) \\
\hline
\end{tabular}

a modular modeling framework that has been developed by the Agricultural Production Systems Research Unit in Australia (Keating et al., 2003). APSIM was developed to simulate biophysical process in farming systems, in particular where there is interest in the economic and ecological outcomes of management practices in the face of climatic risk.

It is a modular framework. Its modules include a diverse range of crops, pastures and trees, soil processes including water balance, $\mathrm{N}$ and $\mathrm{P}$ transformations, soil $\mathrm{pH}$, erosion and a full range of management controls (manure, fertilizer, weeding, irrigation, etc).

APSIM has been used in a broad range of applications, including support for on-farm decision making, farming systems design for production or resource management objectives, assessment of the value of seasonal climate forecasting, analysis of supply chain issues in agribusiness activities, development of waste management guidelines, risk assessment for government policy making and as a guide to research and education activity (Keating et al., 2003). APSIM implements a high degree of modularity of the various modules and processes (Mccown et al., 1996).

The initial motivation was to improve flexibility to model cropping systems and a wider range of soil and management processes.

It was developed primarily for Australia's agricultural industry, but now supports a variety of applications in many parts of the world. As a result of a relatively high level of funding and scientific and development staffing, model development is more active for APSIM than for any of the other families of crop models. Recently the APSIM-millet model was validated for the Sahelian soils, millet cultivars and climate conditions (Akponikpè, 2008). Multiple DS applications were also implemented ranging from nutrients to climate risk management (Akponikpè, 2008; Akponikpè et al., 2010, Akponikpè et al., 2011, Tidjani and Akponikpe, 2012, Tachie-Obeng et al., 2013).It has been used in semi-arid Africa for other various applications (Table 1) and many other studies are in progress in the region.

\section{DSSAT (CERES and CROPGRO)}

The DS system for agrotechnology transfer Decision Support System for Agrotechnology Transfer (DSSAT) (Jones et al., 2003) has been in use for the last 20 years by researchers worldwide. DSSAT is a product of the decade-long (1982-1993) IBSNAT (International Benchmark Sites Network for Agrotechnology Transfer) project. The basis for the new DSSAT cropping system model (CSM) design is a modular structure in which components separate along scientific discipline lines and are structured to allow easy replacement or addition of modules. It has one Soil module, a Crop Template module which can simulate different crops by defining species input files, an interface to add individual crop models if they have the same design and interface, a Weather module, and a module for dealing with competition for light and water among the soil, plants, and atmosphere. It is also designed for incorporation into various application packages, ranging from those that help researchers adapt and test the CSM to those that operate the DSSAT-CSM to simulate production over time and space for different purposes.

Within DSSAT, the relevant models are CERES, which includes the dryland cereal crops, and CROPGRO for grain legumes (Jones et al., 2003). CERES and CROPGRO (grain legumes) differ considerably in their level of detail, degree of modularity and underlying physiological assumptions. Both CERES models and CROPGRO have undergone some testing and application in semi-arid West Africa (Table 2). Jagtap et al. (1999) describe decision applications in a more subhumid environment in Nigeria. Thornton et al. (1997) developed a prototype GIS-based, real-time yield forecasting system for Burkina Faso that uses CERESMillet and satellite-derived precipitation estimates combined with historic weather data series. CROPGROPeanut performed well in recent experiments in northern Benin (Adomou et al., 2005) and Ghana (Naab et al., 2004) taking into account disease damage. For an experiment at Tara, Niger, CERES-Millet substantially over predicted LAI, biomass, grain yield and soil water 
Table 2. List of various types of applications of the DSSAT crop models in Africa and example references that describe these applications in detail.

\begin{tabular}{|c|c|c|}
\hline Type of application & Crop (Climatic zone and country) & References \\
\hline Crop management & $\begin{array}{l}\text { Millet (semi-arid Niger), Maize (semi-arid } \\
\text { Kenya), Maize (Rwanda) }\end{array}$ & $\begin{array}{l}\text { Fechter et al. (Fechter et al., 1991), Fechter } \\
\text { (1993), Mbabaliye and Wojtkowski (1994), } \\
\text { Wafula (1995), Soler et al. (2008) }\end{array}$ \\
\hline Fertilizer management & Maize (Dry and wet Nigeria), maize (Malawi) & $\begin{array}{l}\text { Jagtap (1999), Thornton et al. (1997), MacCarthy } \\
\text { et al. (2012); Adamou et al. (2012), }\end{array}$ \\
\hline $\begin{array}{l}\text { Irrigation and water } \\
\text { management }\end{array}$ & $\begin{array}{l}\text { Wheat (Egypt), Wheat (Zimbabwe), Millet } \\
\text { under Zaï }\end{array}$ & $\begin{array}{l}\text { Kamel et al. (1995), Macrobert and Savage } \\
\text { (1998); Fatondji et al. (2012). }\end{array}$ \\
\hline Climate change and variability & Maize (Zimbabwe) & Muchena and Iglesia (1995), Phillips et al. (1998) \\
\hline Risk analysis & $\begin{array}{l}\text { Millet (Semi-arid Niger) ; Maize and pasture } \\
\text { (Dryland southern Africa) }\end{array}$ & Bley et al. (1991), Jones and Thornton (2002) \\
\hline Food security & $\begin{array}{l}\text { Millet, (Soudano-Sahelian and Semi-arid } \\
\text { Burkina Faso); Maize (South-Africa) }\end{array}$ & Thornton et al. (1997), Dupisani (1987) \\
\hline
\end{tabular}

content (Fechter et al., 1991). On the other hand, Naab et al. (2004) obtained good predictions of soil water contents and use in groundnut experiments in northern Ghana when values of these hydrological properties were based on field measurements. Recently Soler et al. (2008) used this model for optimal planting date determination for millet in the Sahel. The DSSAT model was used for a better process understanding for several agricultural processes involving the integrated soil fertility management (MacCarthy et al. 2012; Adamou et al., 2012), millet response to the zaï rainwater harversting technique (Fatondji et al., 2012). Models included in DSSAT (including their predecessors) have been used in more regions and for a broader range of applications than any other family of crop models.

\section{STICS}

The 'Simulateur mulTIdisciplinaire pour les Cultures Standards' STICS is a model that has been developed at INRA (France) since 1996 (Brisson et al., 2003). It simulates crop growth as a response to soil water and nitrogen balances driven by climatic conditions. The output are both agricultural variables (yield, input use) and environmental variables (water and nitrogen losses). One of the key elements of STICS is its adaptability to various crops and this is achieved by the use of generic parameters relevant for most crops and on options in the model formalizations concerning both physiology and management that are specific for each crop (Brisson et al., 2003). Folliard et al.(2004) compared modeling of sorghum response to photoperiod to related function implemented in STICS. To our knowledge there have been no applications of this model in semi-arid westAfrica.

\section{CropSyst}

The cropping systems simulation model CropSyst (Bechini et al., 2003) implements model modularity through an object-oriented structure. The result is a relatively user-friendly and flexible simulation environment. CropSyst is one of very few dynamic crop models that incorporates pest (aphid) population dynamics and damage. Its potential use for forecasting spatial distributions of millet yields was demonstrated for Burkina Faso (Badini et al., 1997), but without experimental validation of predictions. It has recently been used for grassland productivity analysis and soil carbon in response to time-controlled rotational grazing in semi-arid Mali (Badini et al., 1997).

\section{Which soil-crop simulation models and how they may help overcome agricultural constraints in the Sahel?}

The main disadvantages of mechanistic and dynamic models approach versus simple empirical models are their complexity, the high demand in data not often available and the limited use and accessibility to stakeholders in the Sahelian region. On the other hand the complex water-nutrient-genotype interaction governing crop growth and development make empirical models inadequate, which limits the usefulness of the latter ones only to an understanding or determination of the most meaningful variables that may explain yield in experiments. Predictability of empirical models in the Sahelian environment is low which makes them unsuitable for long term system analysis. Given the complexity and heterogeneity of Sahelian production systems, the use of dynamic modeling tools seems to be a prerequisite. The reason of data availability which lead to opt for simple models, often delays interest in needed data collection.

Regarding the mechanistic and dynamic models, APSIM and DSSAT stand in good place involving most of the constraints of the millet based systems in the Sahel and benefiting from a long history of collaboration with the scientific community in the area (Table 3 ). But none of them provide a build-in option to explicitly account for soil spatial variability. Nevertheless this shortcoming may 
Table 3. Comparison of crop-soil simulation models according to the main agronomic yield determinants and constraints in the Sahel.

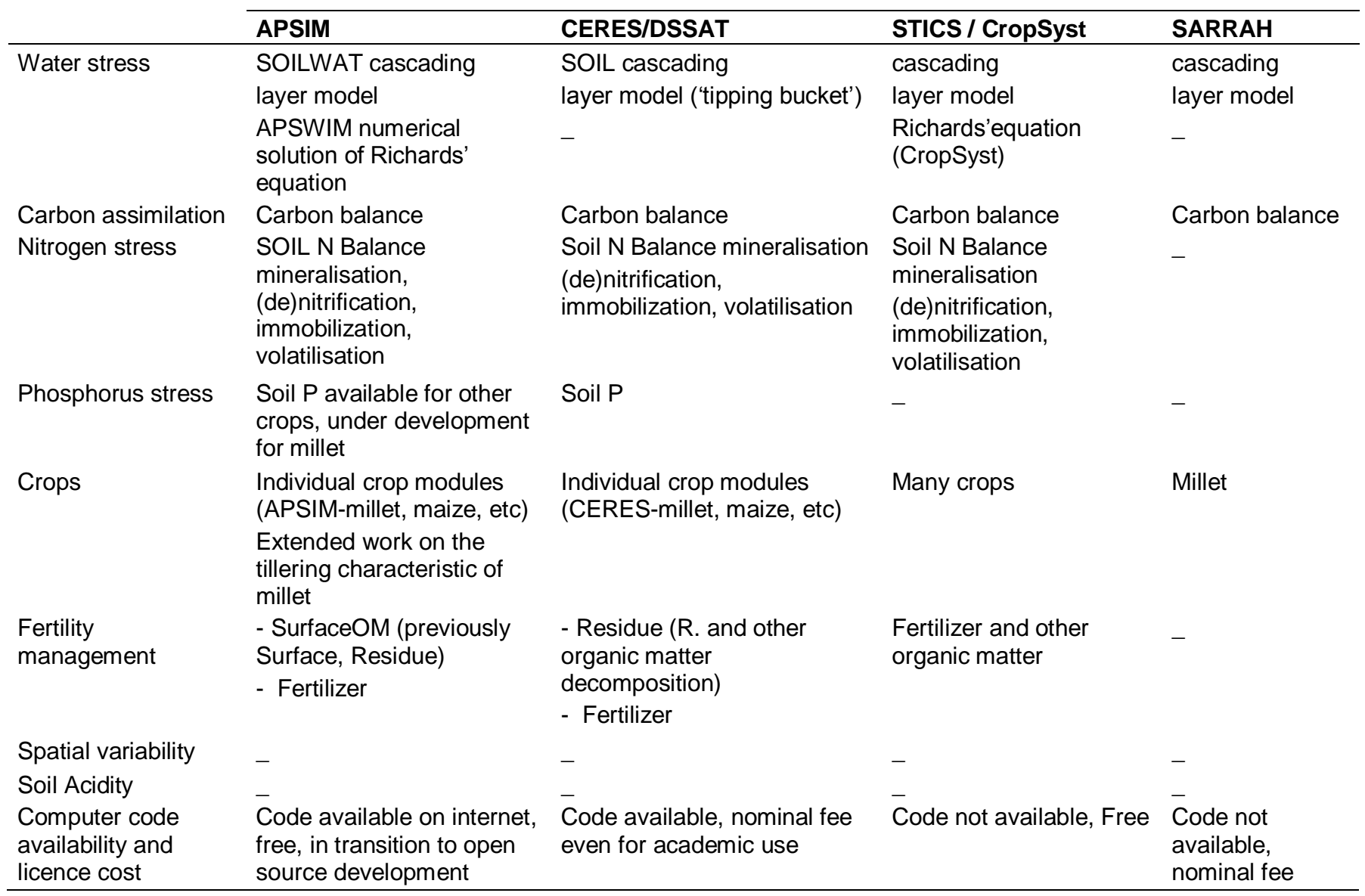

be accounted for by multiple point-level simulations and /or GIS combination (Akponikpè, 2008, Akponikpè et al., 2011) Neither APSIM nor DSSAT are now capable of dealing with $P$ balance, an important millet yield limiting factor in the Sahelian area. Efforts should be made to quickly overcome this shortcoming.

Recently the APSIM model benefited from an extended work on millet module calibration and mainly on its tillering characteristic (Oosterom et al., 2001a, b, 2002). The specific tillering capability of APSIM (based on millet cultivars from semi-arid India) opened the door and guidance for pioneering works of eco-physiological millet characterization in other semi-arid zones, such as the Sahel, which any other crop soil model may benefit from in the future.

Overall the use of numerical crop simulation models is complex, and hardware requirements and computation time are high and generally beyond the capability of technology-transfer specialists.

In the long term, the process of perfect DS systems should evolve into simpler models such as meta-models that constitute an alternative to the use of complex SWCMs.

\section{Conclusion}

The low productivity of the Sahelian millet-based systems is due to poor soil fertility and low and uncertain rainfall conditions. A great wealth of research trials addressed the issue to alleviate the agricultural production constraints with variable results depending on year and agro-ecological environment. Recommendations drawn from research outcomes received limited farmers' interest and adoption because of various reasons (technical, institutional, difference of priority, socio-economical, etc). Several SWCMs exist and are potentially useful for application in the complex and heterogeneous Sahelian agricultural system for DS to save time, money and capitalize on past research trials and farmers local knowledge. Empirical modeling of crop response dates back to the 1930's and was followed by more or less detailed process and dynamic crop modeling development during the past 25 years. But the use of SWCM for DS is still not veritably established in the semiarid west-Africa. Among process models, APSIM and DSSAT are the most promising and efforts are still need to improve their use and effectiveness to deal with the 
main agricultural constraints in the area (water, $\mathrm{N}$ and $\mathrm{P}$ management, the high variability in soil physical and chemical properties).

\section{Conflict of Interests}

The author(s) have not declared any conflict of interests.

\section{ACKNOWLEDGEMENTS}

This review is part of the project entitled 'Improved livelihoods in the Sahel through the development and implementation of household level bio-economic decision support systems' funded by the Belgian Development Cooperation (DGDC). The first author acknowledges further support from the African Climate Change Fellowship Program (ACCFP) by START International.

\section{REFERENCES}

Abdoulaye T, Lowenberg-Deboer J, (2000). Intensification of Sahelian Farming Systems: Evidence From Niger. Agric. Syst. 64:67-81. http://dx.doi.org/10.1016/S0308-521X(00)00014-7

Adamou A, Tabo R, Fatondji D, Hassane O, Bationo A, Adam T (2012). Effect of integrated soil fertility management technologies on the performance of millet in Niger: understanding ther processes using simulation. In Kihara, J., Fatondji D, Jones JW, Hoogenboom G, Tabo R (2012) (Eds) Improving soil fertility recommendations in Africa using the Decision Support System for Agrotechnology Transfer (DSSAT). Springer P. 187.

Adomou M, Prasad PVV, Boote KJ, Detongnon J (2005). Disease assessment methods and their use in simulating growth and yield of peanut crops affected by leafspot disease. Ann. Appl. Biol. 146:469479. http://dx.doi.org/10.1111/j.1744-7348.2005.040122.x

Affholder F (1997). Empirically modelling the interaction between intensification and climatic risk in semiarid regions. Field Crop. Res. 52:79-93. http://dx.doi.org/10.1016/S0378-4290(96)03453-3

Akponikpè PBI (2008). Millet response to water and soil fertility management in the Sahelian Niger : Experiments and modeling. PhD dissertation. Université catholique de Louvain, Louvain-la-neuve, Belgium. P. 168.

Akponikpè PBI, Gérard B, Michels K, Bielders C (2010). Use of the APSIM model in long term simulation to support decision making regarding nitrogen management for pearl millet in the Sahel. Eur. J. Agron. 32:144-154. http://dx.doi.org/10.1016/j.eja.2009.09.005

Akponikpè PBI, Michels K, Bielders CL (2008). Integrated nutrient management of pearl millet in the Sahel using combined application of cattle manure, crop residues and mineral fertilizer. Exp. Agric. 44:453-472. http://dx.doi.org/10.1017/S001447970800673X

Akponikpè PBI, Minet J, Gérard B, Defourny P, Bielders CL (2011). Spatial fields' dispersion as a farmer strategy to reduce agro-climatic risk at the household level in pearl millet-based systems in the Sahel: A modeling perspective. Agric. Forest. Meteorol. 151-2:215-227. http://dx.doi.org/10.1016/j.agrformet.2010.10.007

Badini O, Stockle CO, Franz EH (1997). Application of Crop Simulation Modeling and Gis to Agroclimatic Assessment in Burkina Faso. Agric. Ecosyst. Environ. 64:233-244. http://dx.doi.org/10.1016/S01678809(97)00041-8

Baidu-Forson J (1995). Determinants of the availability of adequate millet stover for mulching in the Sahel. J. Sustain. Agric. 5:101-116. http://dx.doi.org/10.1300/J064v05n01 08

Baron C, Reyniers F, Clopes A, Forest $\bar{F}$ (1999). Applications du logiciel SARRA a l'étude de risques climatiques. Agric. Dev. 24:89-97.

Baron C, Sultan B, Balme M, Sarr B, Traoré S, Lebel T, Janicot S,
Dingkuhn M (2005). From GCM Grid Cell to Agricultural Plot: Scale Issues Affecting Modelling of Climate Impact. Philos. Trans. Royal Soc. B 360:2095-2108.

Bationo A, Buerkert A, Sedogo MP, Christianson BC, Mokwunye AU (1995). A critical review of crop-residue use as soil amendment in the west African semi-arid tropics. In: Livestock and sustainable nutrient cycling in mixed farming systems of sud-Saharan Africa. Vol II: technical papers, Proceedings of an international conference held in Addis Abeba, Ethiopia, 22-26 Nov 1993. ILCA, SGPR, pp. 305-322.

Bationo A, Chien SH, Henao J, Christianson BC, Mokwunye AU (1990a). Agronomic evaluation of two unacidulated and partially acidulated phosphate rocks indigenous to Niger. Soil Sci. Soc. Am. J. 54:1772-1777. http://dx.doi.org/10.2136/sssaj1990.03615995005400060045x

Bationo A, Christianson CB, Baethgen WE (1990b). Plant-Density and Nitrogen-Fertilizer Effects on Pearl-Millet Production in Niger. Agron. J. $82: 290-295$ http://dx.doi.org/10.2134/agronj1990.00021962008200020023x

Bationo A, Christianson CB, Baethgen WE, Mokwunye AU (1992). A Farm-Level Evaluation of Nitrogen and Phosphorus-Fertilizer Use and Planting Density for Pearl-Millet Production in Niger. Fert. Res. 31:175-184. http://dx.doi.org/10.1007/BF01063291

Bationo A, Christianson CB, Klaij MC, (1993). The Effect of Crop Residue and Fertilizer Use on Pearl-Millet Yields in Niger. Fert. Res. 34:251-258. http://dx.doi.org/10.1007/BF00750571

Bationo A, Mokwunye AU (1991a). Role of manures and crop residue in alleviating soil fertility constraints to crop production: With special reference to the Sahelian and Sudanian zones of West Africa. Fert. Res. 29:117-125. http://dx.doi.org/10.1007/BF01048993

Bationo A, Mokwunye AU (1991b). Alleviating Soil Fertility Constraints to Increased Crop Production in West Africa - the Experience in the Sahel. Fert. Res. 29:95-115. http://dx.doi.org/10.1007/BF01048992

Bationo A, Mokwunye U, Vlek PLG, Koala S, Shapiro BI (2003). Soil fertility management for sustainable land use in the West African Sudano-Sahelian zone. In: Soil fertility management in Africa: A regional perspective. Academy Science Publishers (ASP); Centro Internacional de Agricultura Tropical (CIAT); Tropical Soil Biology and Fertility (TSBF), pp. 253-292.

Bationo A, Ntare BR (2000). Rotation and Nitrogen Fertilizer Effects on Pearl Millet, Cowpea and Groundnut Yield and Soil Chemical Properties in a Sandy Soil in the Semi-Arid Tropics, West Afr. J. Agric. Sci.

134:277-284 http://dx.doi.org/10.1017/S0021859699007650

Bazi H, Sanou A, Verberne E, Jongschaap R, Dijksterhuis G, Bonzi M (1995). Manuel du logiciel interactif (CP-BKF3): sorgho, mil et mais. Note 20. In: DLO Institute for Agrobiology and Soil Fertility Research (AB-DLO),

Bechini L, Bocchi S, Maggiore T (2003). Spatial Interpolation of Soil Physical Properties for Irrigation Planning. A Simulation Study in Northern Italy. Eur. J. Agron. 19:1-14.

Bielders CL, Lamers JPA, Michels K, (2001). Wind Erosion Control Technologies in the West African Sahel: the Effectiveness of Windbreaks, Mulching and Soil Tillage, and the Perspective of Farmers. Ann. Arid. Zone 40:369-394.

Bielders CL, Michels K, Bationo A (2002). On-Farm Evaluation of Ridging and Residue Management Options in a Sahelian MilletCowpea Intercrop. 1. Soil Quality Changes. Soil Use Manage. 18:216-222. http://dx.doi.org/10.1111/j.1475-2743.2002.tb00242.x

Bielders CL, Michels K Rajot JL (2000). On-Farm Evaluation of Ridging and Residue Management Practices to Reduce Wind Erosion in Niger. Soil Sci. Soc. Am. J. 64:1776-1785. http://dx.doi.org/10.2136/sssaj2000.6451776x

Bley J, Ploeg RRVD, Sivakumar MVK, Allison BE (1991). A riskprobability map for millet production in southwest Niger. IAHS Publication (International Assoc. Hydrol. Sci. pp. 571-581.

Bouman BAM, Vankeulen H, Vanlaar HH, Rabbinge R (1996). The 'school of De Wit' Crop Growth Simulation Models: a Pedigree and Historical Overview. Agric. Syst. 52:171-198. http://dx.doi.org/10.1016/0308-521X(96)00011-X

Brisson N, Gary C, Justes E, Roche R, Mary B, Ripoche D, Zimmer D, Sierra, J, Bertuzzi P, Burger P, Bussiere F, Cabidoche YM, Cellier P, Debaeke P, Gaudillere JP, Henault C, Maraux F, Seguin B, Sinoquet 
H (2003). An Overview of the Crop Model Stics. Eur. J. Agron. 18:309332. http://dx.doi.org/10.1016/S1161-0301(02)00110-7

Brouwer J, Powell JM (1998). Increasing Nutrient Use Efficiency in West-African Agriculture: the Impact of Micro-Topography on Nutrient Leaching From Cattle and Sheep Manure. Agric. Ecosyst. Environ. 71:229-239. http://dx.doi.org/10.1016/S0167-8809(98)00143-1

Buerkert A, Bationo A, Dossa K (2000). Mechanisms of Residue MulchInduced Cereal Growth Increases in West Afr. Soil Sci. Soc. Am. J. 64:346-358. http://dx.doi.org/10.2136/sssaj2000.641346x

Buerkert A, Bationo A, Piepho HP (2001). Efficient Phosphorus Application Strategies for Increased Crop Production in Sub-Saharan West Africa. Field Crop. Res. 72:1-15. http://dx.doi.org/10.1016/S0378-4290(01)00166-6

Buerkert A, Hiernaux P (1998). Nutrients in the West African SudanoSahelian Zone: Losses, Transfers and Role of External Inputs. Z Pflanz. Bodenkunde http://dx.doi.org/10.1002/jpln.1998.3581610405

Buerkert A, Lamers JPA (1999). Soil Erosion and Deposition Effects on Surface Characteristics and Pearl Millet Growth in the West African Sahel. Plant 215:239-253. http://dx.doi.org/10.1023/A:1004755731732

Buerkert A, Stern RD (1995). Effects of Crop Residue and Phosphorus Application on the Spatial Variability of Nondestructively Measured Millet Growth in the Sahel. Exp. Agric. 31:429-449. http://dx.doi.org/10.1017/S0014479700026429

Chappell A, Agnew CT (2004). Modelling Climate Change in West African Sahel Rainfall (1931-90) as an Artifact of Changing Station Locations. Int. J. Climatol. 24:547-554. http://dx.doi.org/10.1002/joc.1021

Chivenge P, Dimes J, Nhamo N Nzuma JK, Murwira HK (2004). Evaluation of APSIM to simulate maize response to manure inputs in wet and dry regions of Zimbabwe. In: Modelling nutrient management in tropical cropping systems. Canberra, Australian Center for Int. Agric. Res. (ACIAR) 114:85-91.

Christianson CB, Bationo A, Henao J, Vlek PLG (1990). Fate and Efficiency of N-Fertilizers Applied to Pearl-Millet in Niger. Plant Soil. 125:221-231. http://dx.doi.org/10.1007/BF00010660

CLIMAG-WA (2002). Harmonisation of climate prediction for mitigation of global change impact in Sudano-Sahelian west-Africa. In: CLIMAG-West Africa, Volume Proceedings of an international workshop. Plant Reserch International (Netherlands), Institut d'Economie Rurale (Mali), ICRISAT, START (USA).

Dai AG, Lamb PJ, Trenberth KE, Hulme M, Jones PD, Xie PP (2004). The Recent Sahel Drought Is Real. Int. J. Climatol. 24:1323-1331. http://dx.doi.org/10.1002/joc.1083

De Rouw A (2004). Improving Yields and Reducing Risks in Pearl Millet Farming in the African Sahel. Agric. Syst. 81:73-93. http://dx.doi.org/10.1016/j.agsy.2003.09.002

De Rouw A, Rajot JL (2004). Soil Organic Matter, Surface Crusting and Erosion in Sahelian Farming Systems Based on Manuring or Fallowing. Agric. Ecosyst. Environ. 104:263-276. http://dx.doi.org/10.1016/j.agee.2003.12.020

Doorenbos J, Pruitt WO (1977). Crop Water Requirements. FAO Irrigation and Drainage In: FAO, P. 24.

Dourado-Neto D, Teruel DA, Reichardt, K, Nielsen DR, Frizzone JA, Bacchi, OOS (1998a). Principles of crop modeling and simulation: I. uses of mathematical models in agricultural science. Sci. Agron. Piracicaba 55:46-50.

Dourado-Neto D, Teruel DA, Reichardt K, Nielsen DR, Frizzone JA, Bacchi OOS (1998b). Principles of crop modeling and simulation: II. The implication of objectives in model development. Sci. Agric. Piracicaba 55:51-57.

Dupisani Al (1987). The Ceres-Maize Model as a Potential Tool for Drought Assessment in South-Africa. Water Sa 13:159-164.

Enyong LA, Debrah SK, Bationo A (1999). Farmers' Perceptions and Attitudes Towards Introduced Soil-Fertility Enhancing Technologies in Western Africa. Nutr. Cycl. Agroecosys. 53:177-187. http://dx.doi.org/10.1023/A:1009745225465

Esse PC, Buerkert A, Hiernaux P, Assa A (2001). Decomposition of and Nutrient Release From Ruminant Manure on Acid Sandy Soils in the Sahelian Zone of Niger, West Africa. Agric. Ecosyst. Environ. 83:5563. http://dx.doi.org/10.1016/S0167-8809(00)00264-4
Fatondji D (2002). Organic amendment decomposition, nutrient release and nutrient uptake by millet (Pennisetum glaucum $\mathrm{L}$. $\mathrm{R}$. Br) in a traditional land rehabilitation technique (zai) in the Sahel. Ecology and development Series. PhD. Dissertation, University of Bonn. Bonn, Germany 1:147.

Fatondji D, Bationo A, Tabo R, Jones JW, Adamou A, Hassane O (2012). Water use and yield of millet under the zai system: Understanding the processes using simulation. In Kihara, J, Fatondji D, Jones JW, Hoogenboom G, Tabo R (2012). (Eds) Improving soil fertility recommendations in Africa using the Decision Support System for Agrotechnology Transfer (DSSAT). Springer P. 187. http://dx.doi.org/10.1007/978-94-007-2960-5_6

Fatondji D, Martius C, Bielders CL, Vlek PLG, Bationo A, Gérard B (2006). Effect of Planting Technique and Amendment Type on Pearl Millet Yield, Nutrient Uptake, and Water Use on Degraded Land in Niger. Nutr. Cycl. Agroecosys. 76:203-217. http://dx.doi.org/10.1007/s10705-005-6209-9

Fechter J (1993). The simulation of pearl millet (Pennisetum glaucum L.) growth under the environmental conditions of southwestern Niger, West Africa. Ph.D. thesis, Universitaat Hohenheim, Institute fur Bodenkunde und Standorslehre. P. 121.

Fechter J, Allison BE, Sivakumar MVK, Ploeg RRVD, Bley J (1991). Evaluation of the SWATRER and CERES-Millet models for southwest Niger. IAHS Publication (International Association of Hydrological Sciences), pp. 505-513.

Folliard A, Traoré PCS, Vaksmann M, Kouressy M (2004). Modeling of sorghum response to photoperiod: a threshold-hyperbolic approach. Field Crop. Res. 89:59-70. http://dx.doi.org/10.1016/j.fcr.2004.01.006

Fussell LK, Serafini PG, Bationo A, Klaij MC (1987). Management practices to increase yield and yield stability of pearl millet in Africa. In: International Pearl Millet workshop. Proceedings of an international workshop. ICRISAT.

Gandah M, Stein A, Brouwer J, Bouma J (2000). Dynamics of Spatial Variability of Millet Growth and Yields at Three Sites in Niger, West Africa and Implications for Precision Agriculture Research. Agric. Syst. 63:123-140. http://dx.doi.org/10.1016/S0308-521X(99)00076-1

Geiger SC, Manu A (1993). Soil Surface Characteristics and Variability in the Growth of Millet in the Plateau and Valley Region of Western Niger. Agric. Ecosyst. Environ. 45:203-211. http://dx.doi.org/10.1016/0167-8809(93)90071-V

Geiger SC, Manu A, Bationo A (1992). Changes in a Sandy Sahelian Soil Following Crop Residue and Fertilizer Additions. Soil Sci. Soc. Am. J. $56: 172-177$ http://dx.doi.org/10.2136/sssaj1992.03615995005600010027x

Geiger SC, Vandenbeldt RJ, Manu A (1994). Variability in the Growth of Faidherbia-Albida - the Soils Connection. Soil Sci. Soc. Am. J. 58:227-231. http://dx.doi.org/10.2136/sssaj1994.03615995005800010034x

Gérard B, Buerkert A (1999). Aerial Photography to Determine Fertiliser Effects on Pearl Millet and Guiera Senegalensis Growth. Plant Soil. 210:167-177. http://dx.doi.org/10.1023/A:1004633313512

Graef F (2000). Agroclimatology in southwestern Niger - Implication for crop growth and crop management. In: Adapted farming in West Africa: Issues, potentials and perspectives. Verlag Ulrich E. Grauer, pp. 27-31.

Graef F, Haigis J (2001). Spatial and Temporal Rainfall Variability in the Sahel and Its Effects on Farmers' Management Strategies. J. Arid Environ. 48:221-231. http://dx.doi.org/10.1006/jare.2000.0747

Hafner H, George E, Bationo A, Marschner H (1993). Effect of Crop Residues on Root-Growth and Phosphorus Acquisition of Pearl-Millet in an Acid Sandy Soil in Niger. Plant Soil. 150:117-127. http://dx.doi.org/10.1007/BF00779182

Harris F (2002). Management of Manure in Farming Systems in SemiArid West Africa. Exp. Agric. 38:131-148. http://dx.doi.org/10.1017/S0014479702000212

Hiernaux P, Ayantunde A (2004). The Fakara: A semi-arid agroecosystem under stress. Report of research activities. In: ILRI/DMP.

Hoogmoed WB, Klaij MC (1990). Soil-Management for Crop Production in the West African Sahel .1. Soil and Climate Parameters. Soil Till. Res. 16:85-103. http://dx.doi.org/10.1016/0167-1987(90)90023-7

Hoogmoed WB, Stroosnijder L (1984). Crust Formation on Sandy Soils 
in the Sahel .1. Rainfall and Infiltration. Soil Till. Res. 4:5-23. http://dx.doi.org/10.1016/0167-1987(84)90013-8

Hulme M (2001). Climatic perspectives on Sahelian desiccation: 19731998. Global Environ. Chang. 11:19-29. http://dx.doi.org/10.1016/S0959-3780(00)00042-X

INRAN (1990). Rapport d'activité agronomie générale, campagne 1989/1990, Institut de Recherche Agronomique du Niger - Niger, B P. 429 Niamey, Niger.

Jagtap SS, Abamu FJ, Kling JG (1999). Long-term assessment of nitrogen and variety technologies on attainable maize yields in Nigeria using CERES-maize. Agric. Syst. 60:77-86. http://dx.doi.org/10.1016/S0308-521X(99)00019-0

Jones JW, Hoogenboom G, Porter CH, Boote KJ, Batchelor WD, Hunt LA, Wilkens PW, Singh U, Gijsman AJ, Ritchie JT (2003). The Dssat Cropping System Model. Eur. J. Agron. 18:235-265. http://dx.doi.org/10.1016/S1161-0301(02)00107-7

Jones PG, Thornton PK (2002). Spatial modeling of risk in natural resource management. Conserv. Ecol. P. 5.

Kamel A, Schroeder K, Sticklen J, Rafea, A, Salah A, Schulthess U, Ward R, Ritchie J (1995). Integrated wheat crop management based on generic task knowledge-based systems and CERES numerical simulation. Al Applications 9:17-28.

Keating BA, Carberry PS, Hammer GL, Probert ME, Robertson MJ. Holzworth, D, Huth NI, Hargreaves JNG, Meinke H, Hochman Z, Mclean G, Verburg K, Snow V, Dimes JP, Silburn M, Wang E, Brown S, Bristow KL, Asseng, S, Chapman S, Mccown RL, Freebairn DM, Smith CJ (2003). An Overview of Apsim, a Model Designed for Farming Systems Simulation. Eur. J. Agron. 18:267-288. http://dx.doi.org/10.1016/S1161-0301(02)00108-9

Kimani SK, Nandwa SM, Mugendi DN, Obanyi SN, Ojiem J, Murwira HK, Bationo A (2003). Principles of integrated soil fertility management. In: Soil fertility management in Africa: A regional perspective. Academy Science Publishers (ASP); Centro Internacional de Agricultura Tropical (CIAT); Tropical Soil Biology and Fertility (TSBF), pp. 51-72.

Kimetu JM, Mugendi DN, Palm CA, Mutuo PK, Gachengo CN, Bationo A, Nandwa S, Kungu JB (2004). Nitrogen Fertilizer Equivalencies of Organics of Differing Quality and Optimum Combination With Inorganic Nitrogen Source in Central Kenya. Nutr. Cycl. Agroecosys. 68:127-135. http://dx.doi.org/10.1023/B:FRES.0000019043.33580.a6

Kinyangi RJ, Delve J, Probert ME (2004). Testing the APSIM model with data from a phosphorus and nitrogen replenishment experiment on an Oxisol in Western Kenya. In: Modelling nutrient management in tropical cropping systems. Canberra, Australian Center for Int. Agric. Res. (ACIAR) 114:101-109.

Klaij MC, Renard C, Reddy KC (1994). Low-Input Technology Options for Millet-Based Cropping Systems in the Sahel. Exp. Agric. 30:7782. http://dx.doi.org/10.1017/S0014479700023863

Klaij MC, Vachaud G (1992). Seasonal Water-Balance of a Sandy Soil in Niger Cropped With Pearl-Millet, Based on Profile Moisture Measurements. Agric. Water Manage. 21:313-330. http://dx.doi.org/10.1016/0378-3774(92)90053-Y

Kpongor DS (2007). Spatially explicit modeling of sorghum (Sorghum bicolor (L.) Moench) production on complex terrain of a semi-arid region in Ghana using APSIM. Ecology and development Series. PhD. Dissertation, University of Bonn. Bonn, Germany 51:142

Kretzschmar RM, Hafner H, Bationo A, Marschner H (1991). Long-term and short-term effects of crop residues on aluminum toxicity, phosphorus availability and growth of pearl-millet in an acid sandy Soil. Plant Soil. 136:215-223.

Lamers J, Bruentrup M, Buerkert A (1998). The profitability of traditional and innovative mulching techniques using millet crop residues in the West African Sahel. Agric. Ecosyst. Environ. 67:23-35.

Le Barbé LL, Lebel T (1997). Rainfall climatology of the HAPEX-Sahel region during the years 1950-1990. J. Hydrol. 188-189:43-73.

L'hote Y, Mahe G, Some B (2003). Reply to "the Sahelian Drought May Have Ended During the 1990s" the 1990s Rainfall in the Sahel: the Third Driest Decade Since the Beginning of the Century. Hydrol. Sci. J. 48:493-496.

L'hote Y, Mahe G, Some B, Triboulet JP (2002). Analysis of a Sahelian annual rainfall index from 1896 to 2000; the drought continues. Hydrol. Sci. J. 47:563-572.
MacCarthy DS, Sommer R, Vlek PL (2009). Modeling the impacts of contrasting nutrient and residue management practices on grain yield of sorghum (Sorghum bicolor (L.) Moench) in a semi-arid region of Ghana using APSIM. Field Crop. Res. 113:105-115.

MacCarthy DS, Vlek PLG, Fosu-Mensah BY (2012). The response of maize to $\mathrm{N}$ fertilization in a sub-humid region of Ghana:

Understanding the Processes using a crop simulation model. In Kihara J, Fatondji D, Jones JW, Hoogenboom G, Tabo R (2012) (Eds) Improving soil fertility recommendations in Africa using the Decision Support System for Agrotechnology Transfer (DSSAT). Springer P. 187.

Macrobert JF, Savage MJ (1998). The use of a crop simulation model for planning wheat irrigation in Zimbabwe. Understanding options for agricultural production, pp. 205-220.

Manu A, Pfordresher AA, Geiger SC, Wilding LP, Hossner LR (1996). Soil parameters related to crop growth variability in Western Niger, West Africa. Soil Sci. Soc. Am. J. 60:283-288.

Mbabaliye T, Wojtkowski PA (1994). Problems and perspectives on the use of a crop simulation-model in an African Research Station. Exp. Agric. 30:441-446.

Mccown RL, Hammer GL, Hargreaves JNG, Holzworth DP, Freebairn DM (1996). Apsim: A novel software system for model development, model testing and simulation in agricultural systems research. Agric. Syst. 50:255-271.

Michels K, Sivakumar MVK, Allison BE (1995). Wind erosion control using crop residue. Effects on millet establishment and yields. Field Crop. Res. 40:111-118.

Micheni AN, Kihanda FM, Warren GP, Probert ME (2004). Testing the APSIM model with experiment data from the long term manure experiment at Machang'a (Embu), Kenya. In: Modelling nutrient management in tropical cropping systems. Canberra, Australian Center for Int. Agric. Res. (ACIAR) 114:110-117.

Miedema R, Brouwer J, Geiger SC, Vandenbeldt RJ (1994). Variability in the growth of Faidherbia albida near Niamey, Niger, Africa: macromorphology aspects of termites activity. In: Soil Micromorphology: study in management and genesis. Proc. IX Int. Work Meeting on Soil Micromorphology, Townsville, Australia. Developments in Soil Sci. Elsevier, Amsterdam, 22:411-419.

Muchena P, Iglesias A (1995). Vulnerability of maize yields to climate change in different farming sectors in Zimbabwe. Climate change and agriculture: analysis of potential international impacts, Published by American Society of Agronomy; ASA Special Publication, Editors Rosenzweig C, 59:229-239.

Naab JB, Singh P, Boote KJ, Jones JW, Marfo KO (2004). Using the cropgro-peanut model to quantify yield gaps of peanut in the Guinean Savanna Zone of Ghana. Agron. J. 96:1231-1242.

Oosterom EJV, Carberry PS, Hargreaves JNG, O'leary GJ (2001a). Simulating growth, development, and yield of tillering pearl millet II. Simulation of canopy development. Field Crop. Res. 72:67-91.

Oosterom EJV, Carberry PS, O'leary GJ (2001b). Simulating growth, development, and yield of tillering pearl millet I. Leaf area profiles on main shoots and tillers. Field Crop. Res. 72:51-66.

Oosterom EJV, O'leary GJ, Carberry PS, Craufurd PQ (2002). Simulating growth, development, and yield of tillering pearl millet. III. Biomass accumulation and partitioning. Field Crop. Res. 79:85-106.

Ozer P, Erpicum M, Demaree G, Vandiepenbeeck M (2003). The Sahelian drought may have ended during the 1990s: Discussion of "analysis of a Sahelian annual rainfall index from 1896 to 2000: the drought continues". Hydrol. Sci. J. 48:489-492.

Palm CA, Myers RJK, Nandwa SM (1997). Combined use of organic and inorganic nutrient sources for soil fertility maintenance and replenishment. In: Replenishing Soil Fertility in Africa. SSSA Special Publication 51. WI: Soil Science Society of America (SSSA),

Payne WA (2000). Optimizing Crop Water Use in Sparse Stands of Pearl Millet. Agron. J. 92:808-814.

Phillips JG, Cane MA, Rosenzweig C., (1998). ENSO, seasonal rainfall patterns and simulated maize yield variability in Zimbabwe. Agric. Forest Meteorol. 90:39-50.

Powell JM, Fernandezrivera S, Hofs S (1994). Effects of Sheep Diet on Nutrient Cycling in Mixed Farming Systems of Semiarid West-Africa. Agric. Ecosyst. Environ. 48:263-271.

Powell JM, Ikpe FN, Somda ZC, Fernandez-Rivera S (1998). Urine 
Effects on Soil Chemical Properties and the Impact of Urine and Dung on Pearl Millet Yield. Exp. Agric. 34:259-276.

Reardon T, Kelly V, Crawford E, Diagana B, Dione J, Savadogo K, Boughton D (1997). Promoting Sustainable Intensification and Productivity Growth in Sahel Agriculture After Macroeconomic Policy Reform. Food Policy 22:317-327.

Rebafka FP, Hebel A, Bationo A, Stahr K, Marschner H (1994). ShortTerm and Long-Term Effects of Crop Residues and of Phosphorus Fertilization on Pearl-Millet Yield on an Acid Sandy Soil in Niger, West-Africa. Field Crop. Res. 36:113-124.

Reddy KC (1988). Stratégies alternatives pour la production de mil/niébé pendant l'hivernage. Fascicule No. 1. Institut National de Recherches Agronomiques du Niger (INRAN), B P. 429, Niamey, Niger.

Rockstrom J (1999). On-Farm Green Water Estimates as a Tool for Increased Food Production in Water Scarce Regions. Phys. Chem. Earth PT B 24:375-383.

Samba A (1998). Les logiciels DHC de diagnostic hydrique des cultures. Prévision des rendements du mil en zones soudanosahéliennes de l'Afrique de l'Ouest. Cah. Etud. Rech. Fr. I Sécheresse 9:281-288.

Sangaré M, Bationo A, Hiernaux P, Fernandez-Rivera S, Pandey V (2002). Effect of Type and Level of Roughage Offered to Sheep and Urine Addition on Compost Quality and Millet Growth and Production in the Sahel. Nutr. Cycl. Agroecosys. 62:203-208.

Schlecht E, Buerkert A (2004). Organic Inputs and Farmers' Management Strategies in Millet Fields of Western Niger. Geoderma 121:271-289.

Schlecht E, Buerkert A, Tielkes E, Bationo A (2006). A critical analysis of challenges and opportunities for soil fertility restoration in SudanoSahelian West Africa. Nutr. Cycl. Agroecosys. 76:109-136.

Schlecht E, Hiernaux P, Achard F, Turner MD (2004). Livestock related nutrient budgets within village territories in Western Niger. Nutr. Cycl. Agroecosys. 68:199-211.

Scott-Wendt J, Chase RG, Hossner LR (1988a). Soil chemical variability in sandy Ustalfs in semi-arid Niger, West Africa. Soil Sci. 145:414-419.

Scott-Wendt J, Hossner LR, Chase RG (1988b). Variability in Pearl millet (Pennisetum americanum) fields in semiarid west Africa. Arid Soil Res. Rehab. 2:49-58.

Shamudzarira Z, Robertson MJ (2000). Simulating the response of maize to nitrogen fertilizer in semiarid Zimbabwe. Risk management working paper. CIMMYT Series 00/05.

Shamudzarira Z, Robertson MJ (2002). Simulating response of maize to nitrogen fertilizer in semi-arid Zimbabwe. Exp. Agric. 38:79-96.

Shapiro BI, Sanders JH (1998). Fertilizer Use in Semiarid West Africa: Profitability and Supporting Policy. Agric. Syst. 56:467-482.

Sivakumar MVK (1988). Predicting rainy season potential from the onset of rains in southern sahelian and sudanian climatic zones of West Africa. Agron. Forest Meteorol. 42:295-305.

Sivakumar MVK (1990). Exploiting rainy season potential from the onset of rains in the Sahelian Zone of West-Africa. Agron. Forest Meteorol. 51:321-332.

Sivakumar MVK (1992). Climate change and implications for agriculture in Niger. Climatic Change 20:297-312.

Sivakumar MVK, Maidoukia A, Stern RD (1993). Agroclimatology of West Africa: Niger. Information Bulletin P. 5.

Soler C, Maman N, Zhang X, Mason S, Hoogenboom G (2008). Determining optimum planting dates for pearl millet for two contrasting environments using a modelling approach. J. Agric. Sci. 146:445-459.

Struif Bontkes T, Wopereis M (2003). Decision support tools for smallholder agriculture in Sub-Saharan Africa: A practical guide. IFDC ;ACP-EU Technical Centere for Agricultural and Rural Cooperation, Muscle Shoals Ala. U.S.A.; Wageningen Netherlands.

Subbarao GV, Renard C, Bationo A, van Duivenbooden N, Bielders C (1999). Alternative technologies for the Sahelian crop production systems in west Africa. In: Management of Arid Ecosystem. pp. 121132.

Subbarao GV, Renard C, Payne WA, Bationo A (2000). Long-Term effects of tillage, phosphorus fertilization and crop rotation on pearl millet-cowpea productivity in the West-African Sahel. Exp. Agric.
36:243-264

Sultan B, Baron C, Dingkuhn M, Sarr B, Janicot S (2005a). Agricultural impacts of large-scale variability of the West African Monsoon. Agric. Forest. Meteorol. 128:93-110.

Sultan B, Baron C, Dingkuhn M, Sarr B, Janicot S (2005b). La variabilité climatique en Afrique de l'Ouest aux échelles saisonnières et intrasaisonnière. II: Applications à la sensibilité des rendements agricoles au Sahel. Cah. Etud. Rech. Fr. / Sécheresse. 16:23-33.

Tachie-Obeng E, Akponikpè PBI, Adiku S (2013). Considering effective adaptation options to impacts of climate change for maize production in Ghana, Environ. Dev. 5:131-145.

Thompson LM (1986). Climate change, weather variability, and corn production. Agron. J. P. 78.

Thornton PK, Bowen WT, Ravelo AC, Wilkens PW, Farmer G, Brock J, Brink JE (1997). Estimating millet production for famine early warning: an application of crop simulation modelling using satellite and ground-based data in Burkina Faso. Agric. Forest Meteorol. 83:95-112.

Tidjani AM, Akponikpè PBI (2012). Evaluation des stratégies paysannes d'adaptation aux changements Climatiques: Cas de la production du maïs au Nord-Bénin. Afr. Crop Sci. J. 20:493-500.

Tittonell P, Zingore S, Wijk MTV, Corbeels M, Giller KE (2007). Nutrient use efficiencies and crop responses to N,P and Manure Applications in Zimbabwean Soils: Exploring Management Strategies Across Soil Fertility Gradients. Field Crop. Res. 100:348-368.

Ukkerman R, Hama B (1995). Evaluation des systemes de cultures. PRIVAT (Projet participatif de Renforcement des Instititions Villageoises pour le développement de l'Agriculture du Département de Tahoua. B P. 86, Konni, Niger.

Vanlauwe B, Giller KE (2006). Popular myths around soil fertility management in sub-Saharan Africa: Nutrient Management in Tropical Agroecosystems. Agric. Ecosyst. Environ. 116:34-46.

Voortman RL, Brouwer J (2003). An empirical analysis of the simultaneous effects of Nitrogen, Phosphorus and Potassium in Millet Production on Spatially Variable Fields in South-west Niger. Nutr. Cycl. Agroecosys. 66:143-164.

Voortman RL, Brouwer J, Albersen PJ (2004). Characterization of spatial soil variability and its effect on millet yield on Sudano-Sahelian Coversands in Sw Niger. Geoderma 121:65-82.

Wafula BM (1995). Applications of crop simulation in agricultural extension and research in Kenya. Agric. Syst. 49:399-412.

West LT, Wilding LP, Landeck JK, Calhoun FG (1984). Soil Survey of the ICRISAT Sahelian Center, Niger, West Africa.

Williams TO (1999). Factors influencing manure application by farmers in semi-arid west Africa. Nutr. Cycl. Agroecosys. 55:15-22.

Winkel T, Renno J, Payne W (1997). Effect of the timing of water deficit on growth, phenology and yield of pearl millet (Pennisetum glaucum (L.) R. Br.) grown in Sahelian conditions. J. Exp. Bot. 48:1001-1009.

Yamoah CF, Bationo A, Shapiro B, Koala S (2002). Trend and stability analyses of millet yields treated with fertilizer and crop residues in the Sahel. Field Crop. Res. 75:53-62. 